\title{
Recurrent Urethral Diverticulum: A Case Report
}

\author{
Rekürren Üretral Divertikül: Bir Olgu Sunumu
}

\author{
(1) Meredith Lilly', (1) Lee A. Richter² \\ 1 Georgetown University Faculty of Medicine, Department of Urology, Washington DC, USA \\ 2Medstar Washington Hospital Center, Clinic of Urology, Washington DC, USA
}

\begin{abstract}
Recurrence of urethral diverticulum after surgical repair is common and well established in the literature. However, data on the rates of multiple recurrences in the same patient is lacking. Here, we present the case of a 42-year-old female patient with a history of multiple urethral diverticula, who presented with a urethral diverticulum containing a large calculus. Our aim was to review the risk factors and management of patients who present with recurrent urethral diverticula.
\end{abstract}

Keywords: Urethral diverticulum, Stress urinary incontinence, Pelvic surgery

Öz

Cerrahi onarım sonrası üretral divertikül rekürrensi yaygındır ve literatürde iyi bilinmektedir. Bununla birlikte, aynı hastada çoklu rekürrens oranları hakkındaki veriler yetersizdir. Burada, üretral divertikülde büyük bir taş ile başvuran ve çoklu üretral divertikül öyküsü olan 42 yaşındaki bir kadın olgu sunulmuştur. Bu çalışmada, tekrarlayan üretral divertikül ile başvuran hastaların risk faktörlerinin ve yönetiminin gözden geçirilmesi amaçlanmıştır. Anahtar Kelimeler: Üretral divertikül, Stres üriner inkontinans, Pelvik cerrahisi

\section{Introduction}

Female urethral diverticulum (UD) is relatively common, as it affects $1 \%-6 \%$ of women. Diagnosis can be significantly prolonged by non-specific symptoms which include dysuria, recurrent urinary tract infection (UTI), incontinence and dyspareunia. Management is guided by the patient's symptoms, and ranges from observation to surgical intervention. Recurrence of UD after surgery is also common, occurring at a rate between $8 \%$ and $20 \%$. Thus, UD should be suspected in patients with a surgical history of urethral diverticulectomy who present with non-specific urinary symptoms.

\section{Case Presentation}

A 42-year-old (G4P3013) woman with an extensive genitourinary and pelvic surgical history presented with symptoms of recurrent UTI, stress urinary incontinence (SUI) and a feeling of vaginal fullness. Her past medical history included a history of uterine prolapse and recurrent UD, requiring prior surgical interventions as described below.

At age 29 , the patient presented with urinary incontinence and was found to have a UD at an outside hospital. There, she underwent a diverticulectomy, which was complicated the following year by urethrovaginal (UV) fistula and subsequently repaired via a vaginal approach.

At age 34 , the patient presented with stage 3 pelvic organ prolapse, SUI and a recurrence of UD. She subsequently underwent a supracervical hysterectomy with abdominal sacrocolpopexy, rectus fascial sling, and urethral diverticulectomy. Intraoperatively, a recurrent UV fistula was encountered and repaired, with placement of a Martius flap to augment the repair. SUI recurred six months after surgery, and the patient was lost to follow-up.

At age 42 , the patient again presented with symptoms of recurrent UTI, SUI and a feeling of vaginal fullness. She had a history of eight UTIs in the past year and two episodes of pyelonephritis.

Correspondence: Meredith Lilly MD, Georgetown University Faculty of Medicine, Department of Urology, Washington DC, USA

Phone: +7736218051

E-mail: ml1385@georgetown.edu ORCID-ID: orcid.org/0000-0002-3571-4498

Received: 29.06.2017

Accepted: 05.01.2018

Cite this article as: Lilly M, Richter LA. Recurrent Urethral Diverticulum: A Case Report. J Urol Surg 2019;6(1):71-73.

${ }^{\circ}$ Copyright 2019 by the Association of Urological Surgery / Journal of Urological Surgery published by Galenos Publishing House. 
Before outpatient work up could be completed, she presented to the emergency room (ER) with the complaints of severe leftsided back pain, nausea and vomiting. A non-contrast computed tomography scan at the time of ER presentation revealed two large calculi-one partially obstructing the proximal left ureter and one peri-urethral stone measuring $1 \mathrm{~cm}$ in diameter within a posterior proximal UD. After successful treatment of her renal stone, she underwent pelvic magnetic resonance imaging, which revealed a bi-lobed diverticulum with a wide mouthed orifice coming off of the posterior mid urethra (Figure 1A). Each lobe measured $1 \mathrm{~cm}$ in diameter, with the inferior lobe containing a $1.0 \mathrm{~cm}$ calculus (Figure 1B).

The patient subsequently underwent urethral diverticulectomy. An ostium containing a stone in the posterior proximal urethra to the left of midline just distal to the urethrovesical junction was visualized via cystoscopy (Figure 1C). At the mid urethra, there was a transverse band thought to be the previous rectus fascial sling. Next, an inverted U-incision was made on the anterior vaginal wall. The vaginal epithelium was dissected off of the underlying fibromuscular connective tissue to create a U-flap. The previously placed fascial sling was identified, dissected off from the surrounding fibromuscular connective tissue, and divided at the midline. A vertical incision was made over the proximal urethra and the diverticulum sac containing the stone was entered (Figure 1D). The wall of the diverticulum was completely mobilized and transected near the urethral ostium, and the calculus was removed (Figure 1E). The urethrotomy was closed with interrupted sutures of 4-0 Vicryl, with care to include the urothelium on each side. Backfill of the urethra with a Trattner catheter with methylene blue solution demonstrated a watertight closure after a single layer. The rectus fascial sling was re-approximated with two mattress sutures of Vicryl in an overlapping fashion to re-establish support to the urethra. The vaginal incision was closed with horizontal mattress sutures of 2-0 Vicryl.

At 6 months postoperatively, her repair has healed without complication or recurrence, and she is being treated for urge predominant mixed urinary incontinence, without signs of SUI on exam.

Written informed consent was obtained from the patient.

\section{Discussion}

The exact pathogenesis of urethral diverticula remains unknown. The leading theory holds that an obstructed peri-urethral gland becomes infected and forms an abscess which subsequently ruptures into the urethral lumen, creating an ostium (1). Other theories include trauma, mid-urethral sling, peri-urethral bulking agents, and obstetrical complication (1). In many cases, however, the exact cause of UD is unclear, as is the case with
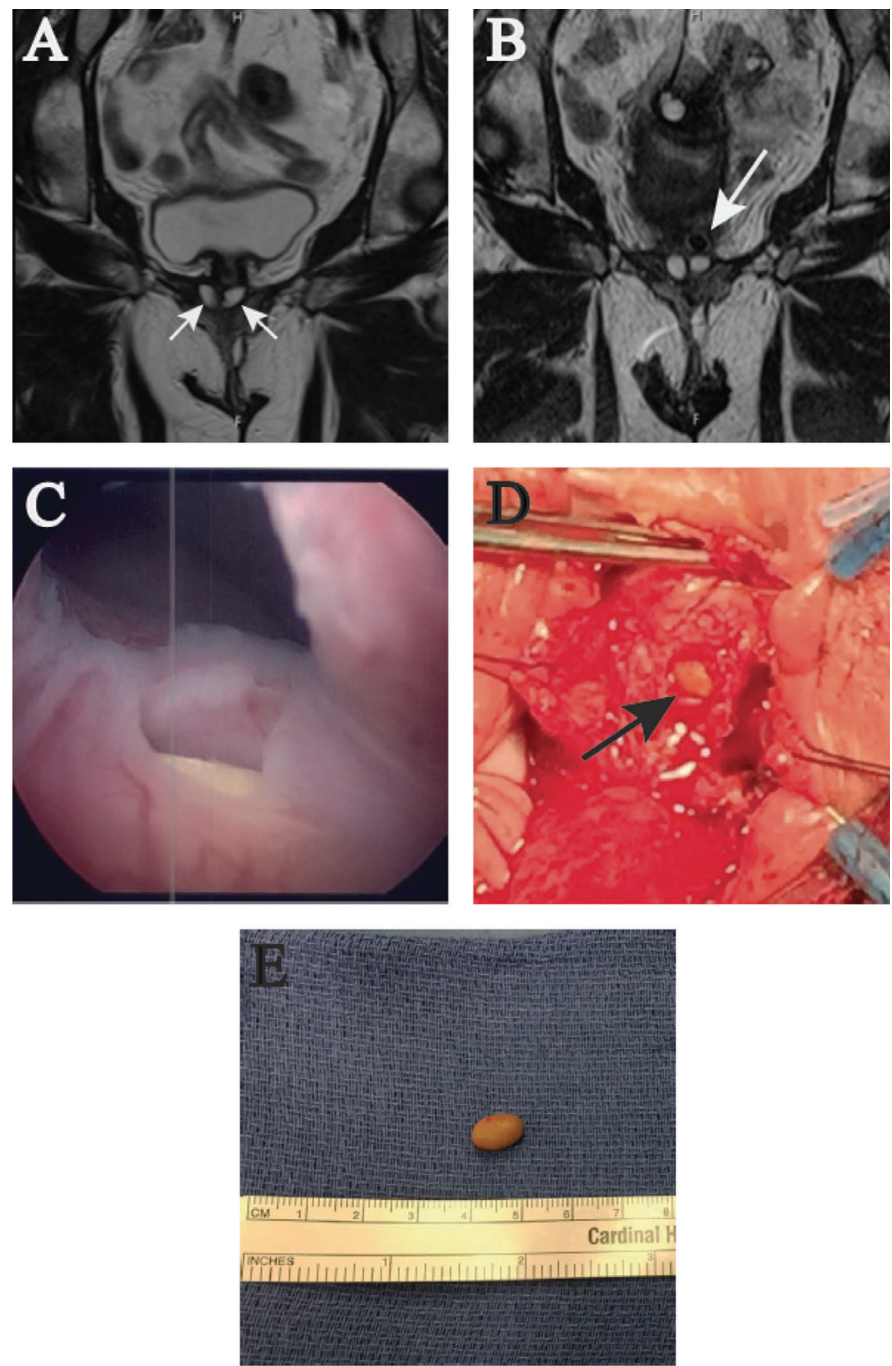

Figure 1. A) T2 weighted magnetic resonance imaging showing bilobed diverticulum (arrows), B) T2 weighted magnetic resonance imaging showing a calculus within the left lobe of the diverticulum (arrow), C) cystoscopy revealing ostium of diverticulum containing a calculus in close proximity to the bladder neck, D) vertical incision and entry into diverticulum sac, E) calculus excised from left lobe of diverticulum

this patient. Definitive treatment of UD is surgical intervention with techniques including marsupialization, endoscopic unroofing, fulguration and most commonly, complete excision with reconstruction (2). Failure to treat UD can result in inflammation and neoplastic degeneration (3), though the exact natural course of untreated UD remains unknown.

This case demonstrates an example of complex UD recurrence. Varying rates of UD recurrence have been reported in the literature and range from $8 \%$ to $17 \%(4,5,6)$, with one group reporting a 5-year recurrence rate of more than 20\% (7). Major risk factors for recurrence have been identified and include history of female pelvic surgery, proximal UD, and prior attempted surgical repair of UD (6). Of note, the patient in this case had all three of these major risk factors. 
SUI is a frequent symptom at presentation in many UD patients, and it can also develop de novo after repair of UD. Whether stress incontinence should be treated at the time of the diverticulectomy or in a delayed procedure is an interesting question, as SUI can be due to the UD and/or be a complication of the UD repair itself. Interestingly, the patient had a history of UV fistula, which is also a potential complication of UD repair (8). The risks of the procedure must be carefully weighed against the patient's symptoms and current quality of life. It was our decision to proceed with the complex repeat UD repair and concomitantly treat the patient's SUI by re-approximating the previously placed rectus fascial sling.

In conclusion, UD is relatively common and presents with symptoms of dysuria, UTI, incontinence and dyspareunia. Recurrent UD occurs in a significant subset of patients, with risk factors including history of female pelvic surgery, proximal UD, and prior attempted repair of UD. Guidelines on management of patients with recurrent UD in the context of multiple surgical repairs are lacking. These patients may need to be more closely followed postoperatively.

\section{Ethics}

Informed Consent: Written informed consent was obtained from the patient.

Peer-review: Internally peer-reviewed.

\section{Authorship Contributions}

Concept: L.A.R., M.L., Design: L.A.R., M.L., Data Collection or Processing: L.A.R., M.L., Analysis or Interpretation: L.A.R., M.L., Literature Search: L.A.R., M.L., Writing: L.A.R., M.L.
Conflict of Interest: No conflict of interest was declared by the authors.

Financial Disclosure: The authors declared that this study received no financial support.

\section{References}

1. Antosh DD, Gutman RE. Diagnosis and management of female urethral diverticulum. Female Pelvic Med Reconstr Surg 2011;17:264-271.

2. Rovner E. Campbell-Walsh Urology. Elsevier, Inc, 2016.

3. Aragona F, Mangano M, Artibani W, Passerini Glazel G. Stone formation in a female urethral diverticulum. Review of the literature. Int Urol Nephrol 1989;21:621-625.

4. Ljungqvist $L$, Peeker $R$ and Fall M. Female urethral diverticulum: 26-year followup of a large series. J Urol 2007;177:219-224.

5. Popat S, Zimmern PE. Long-term outcomes after the excision of horseshoe urethral diverticulum. Int Urogynecol J 2016;27:439-444.

6. Ingber MS, Firoozi F, Vasavada SP, Ching CB, Goldman HB, Moore CK, Rackley RR. Surgically corrected urethral diverticula: long-term voiding dysfunction and reoperation rates. Urology 2011;77:65-69.

7. El-Nashar SA, Singh R, Bacon MM, Kim-Fine S, Occhino JA, Gebhart JB and Klingele CJ. Female Urethral Diverticulum: Presentation, Diagnosis, and Predictors of Outcomes After Surgery. Female Pelvic Med Reconstr Surg 2016;22:447-452.

8. Raup VT, Hess DS, Hanske J, Schmid M, Varda B, Das A, Trinh QD, Eswara JR. Patient Characteristics and Perioperative Outcomes of Female Urethral Diverticulectomy: Analysis of a Multi-Institutional Prospective Database. Urology 2015;86:712-715. 